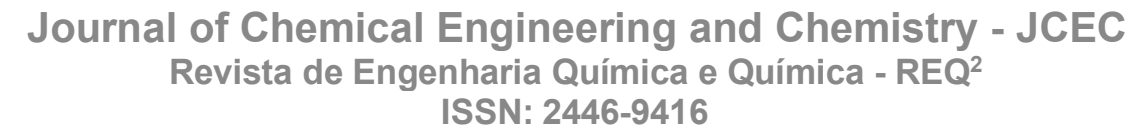

\title{
MICROWAVE IRRADIATION AS AN ALTERNATIVE PROCESS FOR BIODIESEL PRODUCTION USING MACAUBA OIL (Acrocomia aculeata)
}

\author{
M. R. N. PEREIRA ${ }^{1}$, P. P. VALÉRIO' ${ }^{1}$; S. C. GRANDE ${ }^{1}$ e M. H. C. de ANDRADE ${ }^{1}$ \\ ${ }^{1}$ Universidade Federal de Minas Gerais, Departamento de Engenharia Química \\ E-mail: marcos.dequfmg@yahoo.com.br
}

\begin{abstract}
Macauba is an oleaginous palm tree widely found in Brazil. Its productive potential can reach $6000 \mathrm{~kg}$ of oil per hectare. In this study, crude vegetable oil was mechanically extracted from the mesocarp (pulp) of fresh Macauba fruit and subjected to physical-chemical determinations to analyse the following parameters: acid value, moisture content and kinematic viscosity. The results strongly indicate that Macauba palm oil is an alternative source of raw material for biodiesel production. Furthermore, concerning fatty acid composition, a predominance of unsaturated compounds was noted $(75.92 \%)$ of which $63.21 \%$ are oleic acid, and $9.21 \%$ are linoleic acid. In this context, to produce ethyl esters, Macauba palm oil was subjected to alkaline transesterification by homogeneous catalysis, with microwave irradiation being applied to the heating step. The results indicated a conversion rate of $96.6 \%$, for a molar ratio ethanol/oil of $12: 1$, a catalyst concentration equal to $1.0 \mathrm{wt} \%(\mathrm{KOH})$ and a reaction time equal to 60 seconds.
\end{abstract}

KEYWORDS: Macauba palm; Renewable fuel; Microwave; Ethyl esters.

\section{INTRODUCTION}

The global search for innovative ways of meeting the energy demands has led the development of many increasingly efficient systems and technologies. Accordingly, new sources of energy supply are likely to emerge. This new sources, for examples biofuels, tend to generate clean and renewable products. In this sense, biodiesel has excelled on the world stage as a renewable fuel, composed of mono-alkyl esters of long chain fatty acids, which derives from vegetable oils or animal fats. These particular compounds have been broadly used for engines operating by compression. Compared to conventional diesel, the specific physical-chemical properties of biodiesel highlight its global relevance on the alternative fuel scenario (Dwivedi et al., 2011; Masiero e Lopes, 2008; Motasemi and Ani, 2012; Pereira et al., 2014).

Since 2005, soybean oil has emerged as one of the most used inputs for the production of Brazilian biodiesel. It should be noted that since the beginning of the Brazilian National Program for the Production and Use of Biodiesel (NPPB), the utilisation of some particular vegetables, including castor bean, palm oil, cotton seeds and sunflower seeds, has not been truly expressive for the sector of fuel production. The Brazilian National Agency of 
Petroleum, Natural Gas and Biofuels (ANP) officially discloses the profile of materials employed for biodiesel production. The Agency states that $69.8 \%, 22.2 \%, 2.7 \%$ and $5.3 \%$ of the total amount of biodiesel produced in the country are from soybean oil, bovine fat, cotton oil and minority fatty materials, respectively (ANP, 2013; EPE, 2013).

Nowadays, diverse plant raw materials have been used as subjects for studies encompassing biofuel production. For this study, the fruit of Macauba palm tree [Acrocomia aculeata (Jacq.) Lodd. ex Mart.] are mainly proposed as potential substitutes for materials such as soybeans and corn. The use of Macauba coconuts for the biodiesel production is justified by its high oil yield per hectare, as well as by its significant presence in native form in several regions of Brazil. For the heating step, microwave equipment was used and has demonstrated the potential for industrial application. The irradiation aims to decrease reactional times of conventional processes and optimising the biodiesel yield (Pereira et al., 2014; Prates-Valério et al., 2014).

\subsection{Microwave}

Microwaves are electromagnetic radiation, non-ionizing, unable to break chemical connections. Moreover, the energy manifests itself in the form of heat through the interaction with the environment or materials - frequency ranges from $0.3 \mathrm{GHz}$ to $300.0 \mathrm{GHz}$ corresponding to wavelengths varying from $1 \mathrm{~m}$ to $1 \mathrm{~mm}$. To analyse the capacity of microwave energy absorption and the conversion of absorbed energy into heat it is required to compare the capabilities of different substances in generating heat through microwave irradiation. In this way, the relative permittivity or dielectric constant $\left(\epsilon^{\prime}\right)$ represents the capacity of a dielectric material to store electric potential energy - such constant is directly related to the polarity of the molecule. Dielectric Loss factor $\left(\epsilon^{\prime \prime}\right)$, in turn, quantifies the efficiency for the conversion of energy into heat (Lindstrom et al., 2001; Motasemi and Ani, 2012; Varma, 2001).

The capacity of a substance to convert electromagnetic radiation into heat is called Dissipation Factor $(\tan \delta)$. This Factor is mathematically described by the following reason: $\tan \delta=\left(\varepsilon^{\prime \prime} / \varepsilon^{\prime}\right)$. Therefore, the higher the Dissipation Factor the greater the capacity of each substance to be heated by microwave irradiation (Mishra and Rajak, 2004).

Chemistry researchers started using the microwave irradiation in 1980 for organic reactions. The main studies were performed by Gedye \& Guiguere who applied domestic microwave apparatus to provide reactions of both esterification and cycloaddition. The results were compared to the experiments performed using conventional heating making it possible to confirm that microwave experiments can provide substantial increases in reactional speeds whilst reducing the formation of collateral products (Miranda and Souza, 2011).

In discussing medium scale ovens, they usually operate at $2450 \mathrm{MHz}(12.25 \mathrm{~cm}$ wavelength). Companies widely employ the indicated frequency for manufacturing microwave equipment, reinforcing the viable and scientific use, with few exceptions, to chemical processes (Leadbeater and Schmink, 2011). 


\subsection{Transesterification of Vegetable Oils}

Regarding the industrial transesterification process of vegetable oils, in the presence of a catalyst, a molecule of triglyceride reacts with alcohol to produce a mixture of fatty acid esters and glycerol - Figure 01 (Geris et al., 2007).

The overall process is a sequence of three reactions in which monoglycerides and diglycerides are formed as intermediates (Schuchardt et al., 1998). Under the stoichiometry perspective, the reaction is complete in a molar ratio of $3: 1(\mathrm{v} / \mathrm{v})$ alcohol:triglyceride.

Due to the reversible nature of the reaction, the transesterification agent (alcohol) must be added in excess to provide the reaction shift towards the formation of products. Therefore, it increases the yield of the esters and promotes the separation of the formed glycerol.

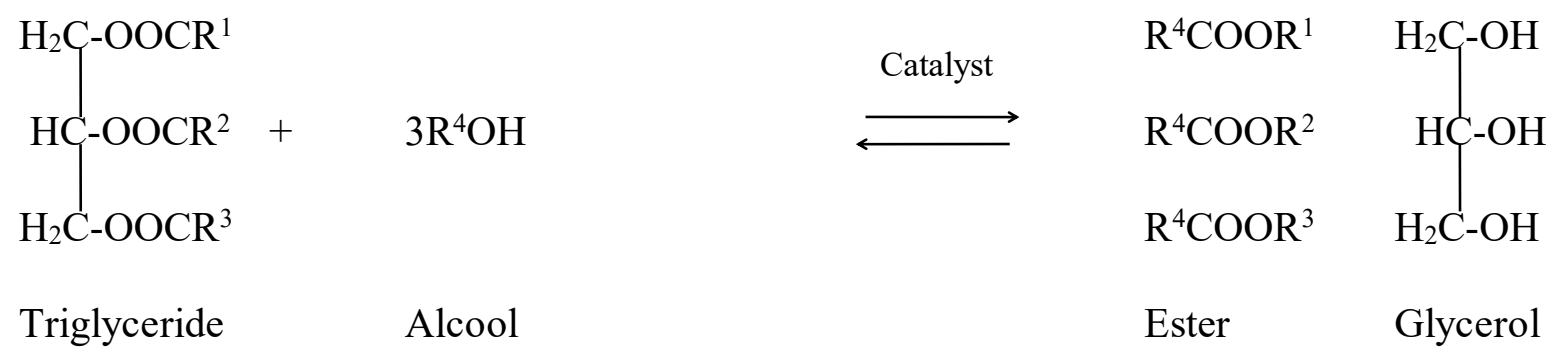

$$
\begin{gathered}
\mathrm{R}^{1}, \mathrm{R}^{2}, \mathrm{R}^{3}=\text { fatty acid carbon chain } \\
\mathrm{R}^{4}=\text { alkyl group of alcohol }
\end{gathered}
$$

Figure 01 - General equation: transesterification of a triglyceride.

\subsection{Homogeneous Base Catalysis}

Base catalysts are used in the processes of biodiesel production enabling high reaction rates with the reduction of overall costs. Catalytic substances also allow the process to be conducted under mild conditions of temperature and pressure. Examples of which being those of hydroxides of alkali metals (mainly: $\mathrm{NaOH}$ and $\mathrm{KOH}$ ) and alkoxides of alkali metals (especially: $\mathrm{NaOCH}_{3}$ and $\mathrm{KOCH}_{3}$ ). The employment of the homogeneous base catalysis is feasible when the transesterification agent (alcohol) is made free of moisture, as well as when the raw material has low levels of free fatty acids (Saqib et al., 2012).

In the alkaline mediums, the transesterification of vegetable oils may originate side reactions with the disadvantage of forming soap either by neutralising the free fatty acids or by saponification of triglycerides and/or mono-alkyl esters.

Side reactions are undesirable due to the catalyst consumption and to the reduction of the ester content. These reactions also commit both glycerol separation process and biodiesel purification (Schuchardt et al., 1988). The following Figure 02 shows some side reactions, which are liable to occur during the transesterification of vegetable oils in the presence of water and/or of free fatty acids. 


\begin{tabular}{|c|c|c|c|c|c|c|}
\hline $\mathrm{R}^{1} \mathrm{COOR}$ & + & $\mathrm{H}_{2} \mathrm{O}$ & $\longleftrightarrow$ & $\mathrm{R}^{1} \mathrm{COOH}$ & + & $\mathrm{ROH}$ \\
\hline $\mathrm{R}^{2} \mathrm{COOR}$ & + & $\mathrm{NaOH}$ & $\rightleftarrows$ & $\mathrm{R}^{2} \mathrm{COONa}$ & + & $\mathrm{ROH}$ \\
\hline $\mathrm{R}^{3} \mathrm{COOH}$ & + & $\mathrm{NaOH}$ & $\rightleftarrows$ & $\mathrm{R}^{3} \mathrm{COONa}$ & + & $\mathrm{H}_{2} \mathrm{O}$ \\
\hline
\end{tabular}

Figure 02 - Side reactions liable to occur during the transesterification of vegetable oils (I) hydrolysis; (II) saponification; (III) neutralisation of free fatty acids.

\subsection{Ethyl Route}

It is noted that the ethyl route has gained in popularity for biodiesel production regarding environmental perspectives. In recent times Brazil is the world largest producer of ethanol from sugarcane (Kohlhepp, 2010). Besides being derived from a renewable raw material, the ethyl route tends to generate a higher number of both cetane and lubricity. Reducing its low toxicity, the use of ethanol thus becomes strategic relevant and directly beneficial to the environmental, economic, political and social implications (Lôbo and Ferreira, 2009).

From a practical point of view, chemical reactions using methanol or ethanol tend to be equivalent - the esters obtained have similar properties to biodiesel fuel. Moreover, at $20^{\circ} \mathrm{C}$ and $2.45 \mathrm{GHz}$, the dissipation factor ( $\tan \delta=0.941$ ) is higher for ethanol in comparison to methanol $(\delta=0.659)$. The use of ethanol is preferable when applying microwave irradiation technique as this alcohol is more capable of converting electromagnetic radiation into heat. By consequence, its use provides greater homogenization whilst increasing the efficiency of converting triglyceride into ethyl ester (Hayes, 2002; Rajak and Misha, 2004).

\subsection{Macauba Palm Tree}

Macauba palm tree belongs to the Arecaceae family, Acrocomia genus and aculeata species. Its distribution occurs throughout the tropical and subtropical Americas, from southern Mexico, the West Indies down to southern Brazil. The vast dispersion of Macauba can be observed in the Brazilian Cerrado forests where its productivity potential is as high as $6000 \mathrm{~kg}$ of oil per hectare. The ripe fruit is spherical, slightly flattened and its diameters range from $3 \mathrm{~cm}$ to $6 \mathrm{~cm}$. This fruit is constituted by a shell (epicarp) its colour being light brown, and the consistency is hard but brittle. The edible pulp (flesh), located under the shell, is sweet and chemically rich in lipids and glycerides. Involving one or two kernels, the pulp has a strongly yellowed colour (Andrade et al., 2006b; Morcote-Rios and Bernal, 2001).

Pulp and kernel together account for around $40 \%$ to $50 \%$ of the total weight of fresh fruit and contain up to $60 \%$ of the total oil content (dry basis). Regarding the fatty acid 
composition, the oil extracted from the pulp of Macauba coconut has a predominance of unsaturated fatty acids (70\% to $80 \%$ ), of which $60-70 \%$ and $8-12 \%$ are oleic and linoleic acids, respectively. On the other hand, the oil extracted from Macauba kernel has a predominance of saturated fatty acids $(67 \%)$ of which $42 \%$ and $30 \%$ are lauric and oleic acids (Coimbra, 2010; Pimenta et al., 2012; Prates-Valério et al., 2014).

\section{MATERIALS AND METHODS}

\subsection{Feedstock}

The raw material used for the examined transesterification via homogeneous base catalysis was composed of crude oil extracted from the mesocarp (pulp) of the Macauba coconut. The fruit were collected from native palms (harvested in 2014), being naturally present in the metropolitan region of Belo Horizonte, Minas Gerais (on the campus of the Federal University of Minas Gerais - UFMG). The ripe fruit were collected, plunged in sodium hypochlorite solution $(5 \%)$ - followed by water wash, and pulped immediately. Until the oil was extracted, pulp were stored at the temperature of $-18^{\circ} \mathrm{C}$. The preparation of pulp for the oil extraction involved thawing, drying (microprocessor oven with forced air circulation, at $60^{\circ} \mathrm{C} / 48$ hours) and comminuting (electric grinder coupled to a stainless steel cup). The mentioned steps were standardised by the research group linked to this study (DEQ-EE/UFMG, 2015). Macauba pulp oil was finally extracted using a continuous mechanical press (Expeller) at a maximum temperature of $35^{\circ} \mathrm{C}$.

\subsection{Analysis of the Macauba Oil Composition}

The Fatty Acid Profile was determined by gas chromatography. The procedure involved the transformation of triglycerides into fatty acids and methylation.

Hydrolysis of lipids: $10 \mathrm{mg}$ of Macauba pulp oil were dissolved in $100 \mathrm{~mL}$ of a solution composed of ethanol $(95 \%)$ /potassium hydroxide $1 \mathrm{~mol} / \mathrm{L}(5 \%)$. The mixture was vortexed for 10 seconds and heated $\left(60\right.$ minutes, $\left.90^{\circ} \mathrm{C}\right)$ in a thermostatic bath (Guo and Qian, 2011). After cooling, $400 \mu \mathrm{L}$ of hydrochloric acid solution $(20 \%), 0.1 \mathrm{~g} \mathrm{NaCl}$ and $600 \mu \mathrm{L}$ of ethyl acetate were added. Vortexing was applied (10 seconds). After standing for $5 \mathrm{~min}$, an aliquot of $300 \mu \mathrm{L}$ of the organic layer was transferred to a cryogenic tube. The free fatty acids were obtained after drying the final solution by evaporation (Christie, 1989).

Fatty Acids Methylation: The free fatty acids were methylated by adding $100 \mu \mathrm{L}$ of a solution consisting of $\mathrm{BF}_{3} /$ methanol (14\%), followed by a heating step (thermostatic bath: 10 min, $80^{\circ} \mathrm{C}$ ). Posteriorly, $400 \mu \mathrm{L}$ of methanol were added. The diluted solution was directly injected into the GC System.

Analytical Parameters: Chromatographic analyses were performed using a GC-2010 equipment (Shimadzu) coupled to a Flame Ionization Detector - FID. The column was a DBWas $(30 \mathrm{~m} \times 0.25 \mathrm{~mm}, 0.25 \mu \mathrm{m}$ film thickness). The following gradient of temperature was applied: $50^{\circ} \mathrm{C}$ ( 2 minutes), $4^{\circ} \mathrm{C} /$ minute to $220^{\circ} \mathrm{C}$ (20 minutes). The temperature of the injector and the detector were set at $250^{\circ} \mathrm{C}$ and $260^{\circ} \mathrm{C}$, respectively. The injection volume 
was equal to $1 \mu \mathrm{L}$ (split ratio $1 / 50$ ). Helium was used as a carrier gas (linear speed: $30 \mathrm{~cm} / \mathrm{s}$ ). The concentrations of Fatty Acid Methyl Esters were based on standard curves plotted using a 37 components FAME mix (Supelco, USA).

\subsection{Physical-Chemical Characterization of Macauba Pulp Oil}

Acid value (AOCS 3d Cd-63): The acid value was determined by diluting $1 \mathrm{~g}$ of pulp macaúba oil in $50 \mathrm{~mL}$ solution of isopropanol:toluene (1:1). The solution was titrated with potassium hydroxide $(0.1 \mathrm{~mol} / \mathrm{L})$ standardised with potassium biphthalate. The acid values were calculated in accordance with the following equations (1) and (2):

$$
\begin{aligned}
& \text { Acid Value }(m g \mathrm{KOH} / \mathrm{g})=(A-B) \times M \times 56.1 / \mathrm{W} \\
& \text { Oleic Acid }(\%)=(A-B) \times M \times 28.2 / \mathrm{W}
\end{aligned}
$$

Where,

$\mathrm{A}=\mathrm{KOH}$ volume $(\mathrm{mL})$ used for the sample titration

$\mathrm{B}=\mathrm{KOH}$ volume $(\mathrm{mL})$ used for the blank titration

$\mathrm{M}=$ molarity of the base, after standardisation

$\mathrm{W}=$ weight $(\mathrm{g})$ of the sample

Moisture content ( $\mathrm{Ca} 2 \mathrm{e}-84$ official method of AOCS): The moisture content was determined by coulometric titration employing the Karl Fischer reagent. The analysis consisted of adding $0.2 \mathrm{~g}$ Macauba pulp oil into the Schott TitroLine KF automatic titrator.

Kinematic viscosity at $40^{\circ} \mathrm{C}$ (ASTM D 2515): The kinematic viscosity was determined at $40^{\circ} \mathrm{C}$ using an automatic viscosimeter (ViscoSystem ${ }^{\circledR}$ AVS 250, Schott Instruments). For this determination, the thermostatic bath was stabilised and $10 \mathrm{~mL}$ of macauba pulp oil were directly added to the equipment. The data were processed by the Software WinVisco 2.12.

All the physicochemical tests were performed in triplicate. The results are presented as a function of averages and standard deviations.

\subsection{Biodiesel Production}

The heating step was carried out in a conventional microwave oven (Electrolux, NEF $28,18 \mathrm{~L}, 1020 \mathrm{~W}, 2450 \mathrm{MHz}$ of frequency). The nominal maximum power of the apparatus was set to $1020 \mathrm{~W}$. In this context, the molar ratio ethanol/oil was defined as $12: 1$. The purities considered for the ethanol and $\mathrm{KOH}$ reagents were $99.8 \%$ and $85.0 \%$, respectively. The following percentages of catalyst $(\mathrm{KOH})$ were evaluated concerning the weight of oil: $0.5 \%, 1.0 \%$ and $1.5 \mathrm{wt} \%$ of oil. Reaction times were analysed at 20, 40, 60, 80 and 100 seconds.

The reactions were performed in Erlenmeyer flasks $(125 \mathrm{ml})$ containing $20 \mathrm{~g}$ of oil. The flasks were homogenised for 3 minutes (200 rpm - MS 300 magnetic stirrer) before being submitted to microwave irradiation. The microwave equipment was employed without the 
need of additional adjustments to consider reflux systems. Excesses of ethanol were held to favour the displacement of the reaction towards the formation of products - also offsetting volatilization losses occurring during the heating step. Tests were performed in duplicate, and the results are presented considering averages and standard deviations.

\subsection{Biodiesel Purification}

After transesterification, samples were centrifuged (Excelsa II BL 206) for 10 minutes, at $3200 \mathrm{rpm}$. It is stated that the less dense phase is rich in ethyl esters whilst the denser phase is rich in glycerol. In this context, three consecutive washes were applied for starting Biodiesel purification. The first washing was carried out with $\mathrm{HCl}$ solution $(0.1 \mathrm{~mol} / \mathrm{L})$. The second and third washes were carried out with distilled water until reaching $\mathrm{pH}$ 7.0.

Along biodiesel purification, it was observed the formation of a stable emulsion. The following tests were performed in order to promote emulsion breakage: heating (30 min at $105^{\circ} \mathrm{C}$ ), saline solution $(\mathrm{NaCl})$, ethanol (polar substance) and 2,2,4 trimethylpentane (nonpolar substance). The results led to the washing steps presented below.

$1^{\text {st }}$ step: $10 \mathrm{~mL}$ of $\mathrm{HCl} 0.1 \mathrm{~mol} / \mathrm{L}+10 \mathrm{~mL}$ of ethanol $+10 \mathrm{~mL}$ de $2,2,4$ trimethylpentane $2^{\text {nd }}$ step: $10 \mathrm{~mL}$ distilled water $+10 \mathrm{~mL}$ de ethanol $+10 \mathrm{~mL}$ de $2,2,4$ trimethylpentane $3^{\text {rd }}$ step: $10 \mathrm{~mL}$ of distilled water $+10 \mathrm{~mL}$ ethanol $+10 \mathrm{~mL}$ de 2,2,4 trimethylpentane

The addition of solvents brings on the need for additional steps to the purification process. In this sense, a volatilization step was carried out on a microprocessor oven with forced air circulation to remove both water and solvent. The time required to volatilize the solvents was recorded as equal to 150 minutes (the boiling temperatures of ethanol and 2,2,4 trimethylpentane are $78.3^{\circ} \mathrm{C}$ and $99.3^{\circ} \mathrm{C}$, respectively). Samples were collected every 15 minutes and weighted using an electrical analytical balance (Ohaus Adventurer) until weight stability was achieved.

\subsection{Ethyl Ester Content}

The ethyl ester content was determined by viscosimetry. The method mathematically correlates alkyl ester content and viscosity (Knothe et al., 2005; Sousa et al., 2013). For this purpose, a calibration curve has been constructed from binary mixtures of soybean oil and biodiesel. The curve covers homogeneous and heterogeneous catalysis and considers the alkyl ester content $(\%)$ and kinematic viscosity $\left(\mathrm{mm}^{2} . \mathrm{s}^{-1}\right)$, at a temperature of $40^{\circ} \mathrm{C}$ (with ethanol). The mentioned mixtures were applied at different proportions of masses being compared to a standard curve obtained by Gas Chromatography. The obtained equation (3) allows monitoring the transesterification of vegetable oils with either high ethyl ester content or viscosity on the order of the soybean oil.

$$
\text { Ethyl ester content }(\%)=160 . \mathrm{e}^{(-v / 9,0)}
$$

Where $v=$ kinematic viscosity at $40^{\circ} \mathrm{C}$. 


\section{RESULTS AND DISCUSSION}

\subsection{Fatty Acids Characterization}

The fatty acid composition of Macauba pulp oil is shown in Table 01 .

Table 01 - Percentage of fatty acids in Macauba pulp oil.

\begin{tabular}{cccc}
\hline Structure & Nomenclature IUPAC & Usual nomenclature & Percentage (\%) \\
\hline C4:0 & Butanoic acid & Butyric & 1.65 \\
C16:0 & Hexadecanoic acid & Palmitic & 18.25 \\
C16:1 & 9-hexadecenoic acid & Palmitoleic & 1.72 \\
C18:0 & Octadecenoic acid & Estearic & 3.45 \\
C18:1n9c & 9-octadecenoic acid & Oleic & 63.21 \\
C18:2n6c & $9,12-$-octadecadienoic acid & Linoleic & 9.21 \\
C18:3n3 & $9,12,15$-octadecatrienoic acid & Linolênic & 0.84 \\
C20:1n9 & 9-eicosenoic acid & Gadoleic & 0.85 \\
C22:0 & Docosanoic-acid & Behenic & 0.12 \\
C24:1n9 & 15-tetracosenoic-acid & Nervonic & 0.09 \\
\hline Unsaturated Fatty Acids & & $\mathbf{7 5 . 9 2}$ \\
Saturated Fatty Acids & & $\mathbf{2 3 . 4 7}$ \\
Total & & & $\mathbf{9 9 . 3 9}$ \\
\hline
\end{tabular}

IUPAC = International Union of Pure and Applied Chemistry

The main fatty acids present in the composition of Macauba pulp oil are the oleic $(63.21 \%)$, palmitic $(18.25 \%)$ and linoleic $(9.21 \%)$. The high content of oleic acid present in the oil directly influences the biodiesel properties. These properties are highly dependent on the carbon chains length and on the degree of unsaturation of the acids. Particularly to the oleic acid, its carbon chain tends to favour the formation of ethyl esters with cis conformation. As a consequence, there is a decrease in the effectiveness of the Van der Waals interactions accompanied by both sterical disadvantages and reduction in the biodiesel viscosity.

\subsection{Physical-Chemical Analysis of Macauba Pulp Oil}

In the context of biodiesel production, the determination of physical-chemical parameters of raw materials is relevant to ascertain the feasibility of the final product. The determination is necessary to define the most appropriate route. Table 02 shows the result obtained for the physicochemical analysis carried out for the Macauba pulp oil. 
Table 02 - Physical-Chemical Properties: Macauba pulp oil.

\begin{tabular}{cc}
\hline Parameters & Results \\
\hline Acid Value $(\mathrm{mg} \mathrm{KOH} / \mathrm{g})$ & $4.03 \pm 0.18$ \\
Acid Value - oleic acid $(\%)$ & $2.02 \pm 0.08$ \\
Moisture Content $(\%)$ & $0.27 \pm 0.05$ \\
Kinematic Viscosity at $40^{\circ} \mathrm{C}\left(\mathrm{mm}^{2} . \mathrm{s}^{-1}\right)$ & $40.04 \pm 0.95$ \\
\hline
\end{tabular}

The acid value was determined according to the amount of free fatty acids (FFA) in the products and feedstock. High acid values can provide parallel reactions which are undesirable for competing with the transesterification reaction. By consequence, it reduces the conversion yield of esters. Accordingly to Meher et al. (2006), the acid value ( $\%$ of oleic acid) found for the Macauba pulp oil $(2.02 \pm 0.08 \%)$ is suitable for transesterification reaction via homogeneous base catalysis.

The determination of the moisture content is essential to assess biodiesel production whilst defining the proper route. The excess of water tends to shift the chemical equilibrium for the alkoxide hydrolysis. The consequence is the production of the corresponding alcohol and the metal hydroxides used as an alkoxide counter-ion. It induces the hydrolysis of triglycerides and monoesters increasing the free fatty acids content. In this sense, moisture contents have to be maintained as low as possible for raw materials in order to avoid parallel reactions that can reduce the conversion index. The result found for moisture content $(0.27 \pm$ $0.05 \%$ ) suggests that the oil is suitable for homogeneous transesterification.

The viscosity is a parameter that can limit the choice of raw materials for originating biodiesel. The value found for the kinematic viscosity was equal to $40.04 \pm 0.95 \mathrm{~mm}^{2} \cdot \mathrm{s}^{-1}$ (at $40^{\circ} \mathrm{C}$ ). As the oleic acid is the major fatty acid in Macauba oil $(63.21 \%)$, it is possible to consider that its triglyceride (kinematic viscosity: $32.94 \mathrm{~mm}^{2} \cdot \mathrm{s}^{-1}$ ) also influences the kinematic viscosity of the feedstock (at $40^{\circ} \mathrm{C}$ ). An analogous influence of free fatty acids, mainly oleic acid (kinematic viscosity of oleic acid, at $40^{\circ} \mathrm{C}: 19.91 \mathrm{~mm}^{2} \cdot \mathrm{s}^{-1}$ ), can also be observed (Knothe and Steidley, 2005).

The results found for the physicochemical properties demonstrate that the Macauba pulp oil is suitable for the purpose of homogeneous base catalysis.

\subsection{Transesterification by Homogeneous Base Catalysis}

Ethyl ester content: The ethyl ester content was obtained after transesterification. Figure 01 shows the ethyl ester conversion rate over time. The results consider a molar ratio of 12:1 (ethanol/oil) and catalyst concentrations $(\mathrm{KOH})$ equal to $0.5,1.0$ and $1.5 \mathrm{wt} \%$ of oil. 


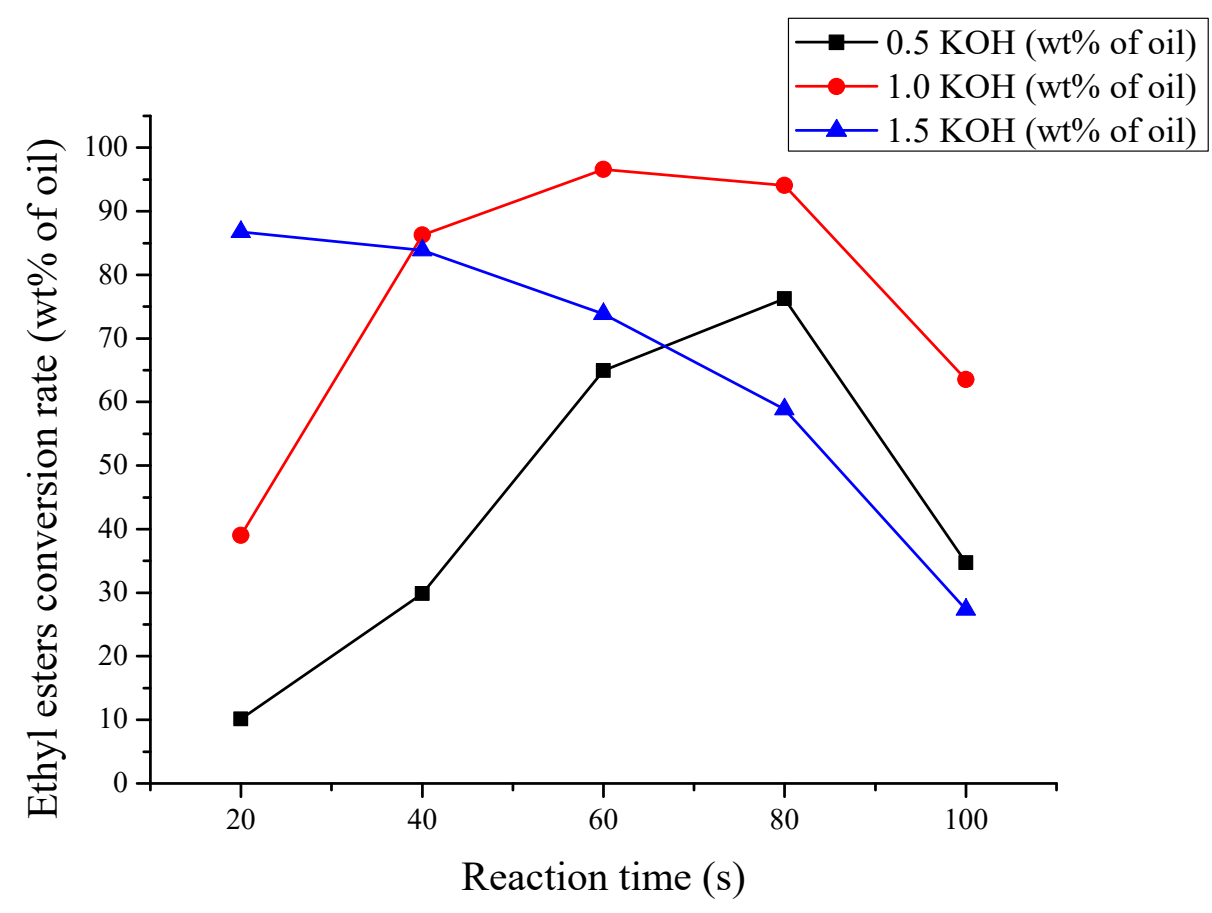

Figure 03 - Effect of different concentrations of $\mathrm{KOH}$ and ethyl ester conversion rate over time.

Regarding the results observed, the reaction time and the catalyst $(\mathrm{KOH})$ concentration influence the ethyl ester conversion rate. For the catalyst concentration equal to $0.5 \mathrm{wt} \%$, it was observed a percentage of $76.25 \pm 1.54 \%$ for ethyl ester conversion rate. For the same concentration, however, there was a decrease in the conversion rate after 80 seconds - the decrease can be explained by the likely occurrence of side reactions.

It can be stated that microwaves irradiation is highly sensitive to the reaction time. For the samples containing the catalyst concentration equal to $0.5 \mathrm{wt} \%$, it was observed a decrease higher than $41 \%$ of the conversion rate, as a result of a 20 seconds variation in the reaction time. The fact can again be explained by the occurrence of side reactions. Additionally, the volatilization of the transesterification agent (ethanol) also influences the mentioned decrease.

The presented Figure 03 notably confirms the existence of optimum values of both time (60 seconds) and catalyst concentration $(1.0 \mathrm{wt} \%)$ for obtaining maximum ethyl ester content. After reaching the highest content $(96.61 \pm 2.32 \%)$, the prospective occurrence of saponification and neutralisation reactions culminated in increasing the level of viscosity. Hence, the ethyl ester content tended to reduce.

In comparison to the concentration of $\mathrm{KOH}$ equal to $1.0 \mathrm{wt} \%$, an increase of $31.6 \%$ for the ethyl ester conversion was observed (reaction time: 60 seconds) for the concentration of catalyst equal to $0.5 \mathrm{wt} \%$. The fact attests the influence of the catalyst in the ethyl ester conversion. For this study, the optimal conversion rate was observed when applying $1.0 \mathrm{wt} \%$ catalyst. For this condition, the ethyl ester content was $20.4 \%$ higher than when compared to the results obtained when applying $0.5 \mathrm{wt} \%$ of $\mathrm{KOH}$. 
When applying the catalyst concentration equal to $1.5 \mathrm{wt} \%$, it was observed that the maximum conversion of triglyceride to ethyl ester happened after 20 seconds. However, the reaction did not reach full conversion in this condition. The content of ethyl ester was equal to $86.74 \pm 1.68 \%$ after 20 seconds.

\section{CONCLUSION}

The Brazilian National Program for the Production and Use of Biodiesel (Brazilian PNPB) intends to ensure the economic viability of biofuel production. The Program provides social inclusion and regional development while promoting diversification in the use of diverse raw materials. In this context, this study validates the potential of Macauba coconuts (Acrocomia aculeata) as a vegetable source of crude oil for the biodiesel production. The tests carried out in this study involved heating and microwave irradiation. The results indicated that the apparatus is technically promising for industry application. It is noteworthy, however, that adjustments to catalyst concentration and reaction time are required depending on the process and the power of the equipment. From these adjustments, the technique proves to be able to contribute to high ethyl ester conversion rates in relatively short reaction times. In this regard, the microwave irradiation is shown to be an economically viable technique, especially when considering continuous processing and industrial production scale. It is worth noting that the mentioned technique can be an option for the existing plants of biodiesel production. In consonance to this study, the total replacement of methanol by ethanol would also be included as an environmental choice. Brazil is the world largest producer of ethanol from sugarcane. Therefore, the mentioned replacement is widely attractive. In this sense, Brazilian biodiesel can be produced from fully renewable resources.

\section{ACKNOWLEDGMENT}

The authors would like to thanks, CAPES - for the Master and Doctoral Scholarships, EMBRAPA, FINEP, FAPEMIG, and $\mathrm{CNPq}$ - for the financial support, and to the Department of Chemical Engineering - DEQ/EE/UFMG.

\section{REFERENCES}

ANDRADE, M. H. C.; VIEIRA, A. S.; AGUIAR, H. F.; CHAVES, J. F. N.; NEVES, R. M. P. S.; MIRANDA, T. L. S.; SALUM, A, 2006a. Óleo do Fruto da Palmeira Macaúba Parte I: Uma Aplicação Potencial Para Indústrias de Alimentos, Fármacos e Cosméticos. In: II ENBTEQ - Encontro Brasileiro sobre Tecnologia na Indústria Química/III Seminário ABIQUIM de Tecnologia. São Paulo. Anais...

ANDRADE, M. H. C.; VIEIRA, A. S.; AGUIAR, H. F.; CHAVES, J. F. N.; NEVES, R. M. P. S.; MIRANDA, T. L. S.; SALUM, A, 2006b. Óleo do Fruto da Palmeira Macaúba Parte II: Processo de Extração do Óleo. In: II ENBTEQ - Encontro Brasileiro sobre Tecnologia na Indústria Química/III Seminário ABIQUIM de Tecnologia. São Paulo. Anais...

ANP. Agência Nacional do Petróleo, Gás Natural e Biocombustíveis. Boletim Mensal do biodiesel, nov, p. 11, 2013. Available at: http:/www.anp.gov.br/?pg=9205. Access in: 15 Jul. 2015. 
EPE. Empresa de Pesquisa Energética. Plano Decenal de Expansão de Energia 2022, p. 312, 2013. Available at: http://www.epe.gov.br/pdee/forms/epeestudo.aspx. Acess in: 08 Dec. 2014.

CHRISTIE, W. W. Gas Chromatography and Lipids. Pergamon Press, Oxford, 1989.

COIMBRA, M. C. Caracterização dos Frutos e dos Óleos Extraídos da Polpa e Amêndoa de Guariroba (Syagrus Oleracea), Jerivá (Syagrus Romanzoffiana) e Macaúba (Acrocomia Aculeata). 2010. 92 f. Dissertação (Mestrado em Engenharia e Ciência de Alimentos) - Universidade Estadual Paulista, São José do Rio Preto, SP, 2010.

DEQ-EE. UFMG. Grupo de Pesquisa - Desenvolvimento de Processos e Produtos da Macaúba, Departamento de Engenharia Química, UFMG, 2015.

DWIVEDI, G; JAIN, S; SHARMA, M. P. Impact analysis of biodiesel on engine performance - A review. Renew. Sust. Energ. Rev., v.15, p. 4633 - 4641, Dec, 2011.

GERIS, R.; SANTOS, N. A. C.; AMARAL, B. A.; MAIA, I. S.; CASTRO, V. D.; CARVALHO, J. R. M. Biodiesel de soja - reação de transesterificação para as aulas práticas de química orgânica. Quím. Nova, v. 30, n. 5, p. 1-8, Sept/Oct, 2007.

GUO, H.; HU, C.; QIAN, J. Determination of Underivatized Long Chain Fatty Acids Using HPLC with an Evaporative Light-Scattering Detector. J. Am. Oil Chem. Soc., v. 89, p. 183-187, Feb, 2011.

HAYES, B. L; Microwave synthesis: chemistry at the speed of light, CEM Publishing, Matthews, NC, 2002.

KNOTHE, G.; GERPEN, J. V.; KRAHL, J. The Biodiesel Handbook, AOCS Press, Illinois, 2005.

KNOTHE, G.; STEIDLEY, K. R. Kinematic viscosity of biodiesel fuel components and related compounds. Influence of compound structure and comparison to petrodiesel fuel components. Fuel, v. 84, p. 1059-1065, Jun, 2005.

KOHLHEPP, G. Análise da situação da produção de etanol e biodiesel no Brasil. Estud. Av., v. 24, n. 68, p. $223-253,2010$.

LEADBEATER, N. E.; SCHMINK, J. R. Microwave Heating as a Tool for Sustainable Chemistry: An Introduction. Nova York: CRC Press, 2011.

LIDSTROM. P.; TIERNEY, J.; WATHEY, B.; WESTAN, J. Microware assisted organic synthesis- a review. Tethaedron, v. 57, n. 589, p. 9225-9232, Nov, 2001.

LÔBO, I. P.; FERREIRA, S. L. C. Biodiesel: Parâmetro de Qualidade e Métodos Analíticos. Quím. Nova, v. 32, n. 6, p. 1596 - 1608, Jul, 2009.

MASIERO, L.; LOPES, H. Etanol e biodiesel como recursos energéticos alternativos: perspectivas da América Latina e da Ásia. Rev. Bras. Polít. Int., v. 51, n. 2, p. 60-79, 2008.

MEHER, L. C.; SAGAR, D. V.; NAIK, S. N. Technical aspects of biodiesel production by transesterification - a review. Renew. Sust. Energ. Rev., v. 10, p. 248-268, Jun, 2006.

MIRANDA, L. S. M.; SOUZA, R. O. M. A. Irradiação de microondas aplicada síntese orgânica: uma história de sucesso no Brasil. Quím. Nova, v. 34, n. 3, p. 1-19, Jan, 2011.

MISHRA, P.; RAJAK, H. Microware-assisted combinatorial chemistry: The potential approach for acceleration of drug discovery. J. Sci. Ind. Res., v. 63, p. 541-654, Aug, 2004.

MORCOTE-RIOS, G.; BERNAL, R. Remains of palms (Palmae) at archaeological sites in the New Word: a review. The Botanical Review, New York, v.67, p. 309-350, Jul/Sept, 2001 . 
MOTASEMI, F.; ANI, F. N. A review on microwave-assisted production of biodiesel. Renew. Sust. Energ. Rev., v. 16, p. 4719-4733, Sept, 2012.

PEREIRA, M. R. N.; VALÉRIO, P. P.; GRANDE, S. C.; CREN, E. C.; De ANDRADE; M. H. C. Obtenção de Ésteres Etílicos via Transesterificação por Catálise Homogênea de Óleo de Macaúba (Acrocomia aculeata (Jacq.) Lodd. ex Mart.) com Aquecimento por Irradiação com Micro-Ondas. In: XX COBEQ. Florianópolis, SC, 2014.

PIMENTA, T. V.; ANDRADE, M. H. C.; ANTONIASSI, R. Extração, Neutralização e Caracterização dos Óleos do Fruto da Macaúba (Acrocomia Aculeata). In: XIX Congresso Brasileiro de Engenharia Química, Búzios, Rio de Janeiro, 2012.

PRATES-VALERIO, P.; GRANDE, S. C.; DE ANDRADE, M. H. C.; CREN, E. C. Perspectivas para um Novo Produto Alimentício à base de Óleo Extraído do Fruto da Macaúba (Acrocomia aculeata (jacq.) lodd. ex mart). In: XX COBEQ. Florianópolis, SC, 2014.

SAQIB, M.; MUMTAZ, M. W.; MAHMOOD, A.; ABDULLAH, M. I. Optimized Biodiesel Production and Environmental Assessment of Produced Biodiesel. Biotechnology and Bioprocess Engineering., v. 17, p. 617-623, Jun, 2012.

SCHUCHARDT, U.; SERCHELI, R.; VARGAS, R. M. Transesterification of Vegetable Oils: a Review. J. Braz. Chem. Soc., v, 9, n. 1, p. 199-210, 1998.

SOUSA, F. P.; LUCIANO, M. A.; PASA, V. M. D. Thermogravimetry and Viscometry for Assessing the Ester Content (FAME and FAEE). Fuel Process. Technol., v. 109, p. 133-140, May, 2013.

VARMA, R. J. Solvent-free accelerated organic syntheses using microwaves. Pure Appl. Chem., v. 73, n. 1, p. 193-198, Jan, 2001.

\title{
IRRADIAÇÃO DE MICROONDAS COMO PROCESSO ALTERNATIVO PARA PRODUÇÃO DE BIODIESEL USANDO ÓLEO DE MACAÚBA (Acrocomia aculeata)
}

\begin{abstract}
RESUMO: Macaúba é uma palmeira oleaginosa largamente encontrada no Brasil e com potencial para produzir cerca de $6,000 \mathrm{~kg}$ de óleo por hectare. Neste trabalho, o óleo foi extraído da polpa fresca do coco de macaúba e algumas propriedades foram determinadas. Os valores do índice de acidez, teor de humidade e viscosidade cinemática indicam que este óleo é altamente recomendado como uma alternativa promissora para a produção de biodiesel. Além disso, a composição de ácidos graxos tem uma predominância de ácidos insaturados $(75,9 \%)$, dos quais $63,2 \%$ e $9,2 \%$ são oleico e linoleico, respectivamente. Sequencialmente, este óleo foi submetido à produção de ésteres etílicos por transesterificação alcalina homogênea, por catálise básica e aplicando aquecimento por irradiação de microondas. Os resultados indicaram uma taxa de conversão de $96,61 \%$ para a razão molar de etanol/óleo de 12:1; concentração de catalisador de $1,0 \%(\mathrm{KOH})$ e tempo de reação de $60 \mathrm{~s}$.
\end{abstract}

PALAVRAS-CHAVE: Palmeira de macaúba; Combustível renovável; Microondas; Ésteres etílicos. 